\title{
Performance of 2-D Frame Equipped With Base isolation System under Dynamic Loadings
}

\author{
$N$. Omprakash Reddy ${ }^{1}$ and $A$. Manchalwar ${ }^{2}$ \\ ${ }^{1} \mathrm{M}$-Tech Scholar, Gokaraju Rangaraju Institute of Engineering and Technology, Hyderabad. \\ ${ }^{2}$ Associate Professor, Gokaraju Rangaraju Institute of Engineering and Technology, Hyderabad
}

\begin{abstract}
Building responses have become a major concern in design research. Passive control techniques are implemented to improve structure efficiency. The present research aims to assess the efficiency of base isolation system for a $2 \mathrm{D}$ frame and to enhance the performance of structures that are subjected to seismic ground excitations and ground vibrations induced by blast. Two moments of resistant RC frames were studied and output of the isolator (Lead / Rubber Bearing) was observed to reduce structural responses. In SAP2000 non-linear dynamic analysis is conducted to compare normal and irregular moment-resistant frames and structural responses with and without passive control techniques. Isolators are constructed based on time of isolation. Reduction of structural responses is assessed by passive control techniques, and comparative analysis is performed. Mitigating systemic retaliation is affected by the implementation of passive control system.
\end{abstract}

\section{Introduction:}

Improvements are being found worldwide in the field of structural engineering. There are many different types of structures being designed depending upon requirements. This is important that these systems are safeguarded from any damage causing events. The structural failure calamities such as earthquakes and blast were a big concern. Base isolation technique are the most commonly used methods of structural enhancement under complex loads in recent years, and Indian codes have developed some guidelines for blast load calculations based on their results. Based on location of the event, there are two types of blasting effects on the structure, ground induced vibrations and above ground vibrations. Non-linear time history analysis is carried out to study the structural reactions under dynamic loads.

In considering its intensity under European regulations, Draganic and Vladimir [1]. Studied the effects of Blast loading on structures. Blast load measurements are obtained from $\mathrm{Ngo}$ et.al [2]. The mechanisms and their impact on the structure. In Omprakash Reddy et al.[3], efficiency of momentary building resistance under dynamic loadings is studied. Blast loading parameters such as peak ground accelerations are determined using study of Ranjan et al[4] for different soil properties. Ruiyang and Brain observe the efficiency of the base isolated structure and its behavior under seismic loading [5]. Kangda and Bakre research LRB (Lead Rubber Bearing) insulator parameters and their performance under dynamic loads [6]. The technique of base isolation and its efficiency is observed in Kangda and Bakre [7]. In Manchalwar and Bakre [8,9], the use of passive control device (X-plate damper) and its effectiveness in mitigating the structural responses are studied for seismic loading. Manchalwar and Bakre determine optimal position for enhancing damper performance in energy dissipation $[12,13,14]$.

\section{Blast and Seismic Loading Calculations}

As observed from the study made by Kangda and Bakre [5] blast loadings considered in present study are taken as ground accelerations ( $\ddot{x}_{\mathrm{g}}$ ) for which the time $(\mathrm{t})$ is taken as exponentially decaying function as mentioned in below equation 1

$$
\ddot{x}_{\mathrm{g}}(\mathrm{t})=\frac{-1}{t d} v e^{-t / t d}
$$


Where $v$ is the peak particle velocity and $t_{d}$ is the arrival time.

Peak particle velocity is calculated from empirical formulae obtained from the study of Deepankar et al [4] as given in Eq. 2 below,

$$
v=\frac{f_{C}^{-0.642} S D^{-1.463}}{\gamma_{D}}
$$

Where SD $\left(\mathrm{m} / \mathrm{kg}^{1 / 2}\right)$ is the scaled distance and is determined as the ratio of distance from charge point $\mathrm{R}(\mathrm{m})$ to the root of charged weight of dynamic loading $\mathrm{Q}(\mathrm{kg}), \mathrm{t}_{\mathrm{d}}=\mathrm{R} / \mathrm{c}$ where $\mathrm{c}$ is the propagation wave velocity $(\mathrm{m} / \mathrm{s})$ in soil, $\mathrm{f}_{\mathrm{c}}$ and $\gamma_{D}$ are the material properties of granite rock deposits in soil.

Seismic loadings considered of higher magnitude across the world namely imperial valley (magnitude $6.6,1979)$, Loma earthquake, kern earthquake and Northridge earthquake (magnitude 6.7, 1994).

\section{Analytical model}

Two moments of resistant RC frames, i.e. normal and irregular frames were considered from the Mondal.et.al [15] and subjected to considered loadings to test efficiency of base isolation. In Indian code IS 1893, irregular frame configuration is studied. For a time interval of $t=0.0005$, all seismic and blast loadings are called ground accelerations as blast activity occurs in a few milliseconds. Analysis of the nonlinear time history is carried out in SAP2000. These considered structures' structural behaviour against dynamic loadings is obtained and shown in table 1 and 2. The foundation insulation device is then introduced into the structure and comparative work is carried out on their performance under dynamic load

\section{Base-Isolation System-Regular Irregular Structure}

and

Base isolation technique is one of the popular methods to reduce structural responses for dynamic loading. Base isolation reduces structural displacements and also dissipates the amount of energy incurred in the structure and also provides decoupling to the structure which reduces structural reactions for dynamic loading. In present work isolators are constructed according to the structural period of the structure i.e., $\mathrm{Tb}=2 \mathrm{Ts}, \mathrm{Tb}=2.5 \mathrm{Ts}$, and
$\mathrm{Tb}=3 \mathrm{Ts}$ where $\mathrm{Tb}$ is the period of isolation and $\mathrm{Ts}$ is the structural period and isolator properties are considered as shown in table no.3. The findings show the efficiency of the use of lead rubber bearing insulator in minimizing structure displacements for both normal and irregular buildings. It is observed that for considered column $\mathrm{C} 1$ percentage reduction in base shear is between 80 to 90 percent for both dynamic loads and also reduction in bending time is between 50 to 60 percent for blast loading and 20 to 60 percent for seismic loading in both regular and irregular structures as shown below.

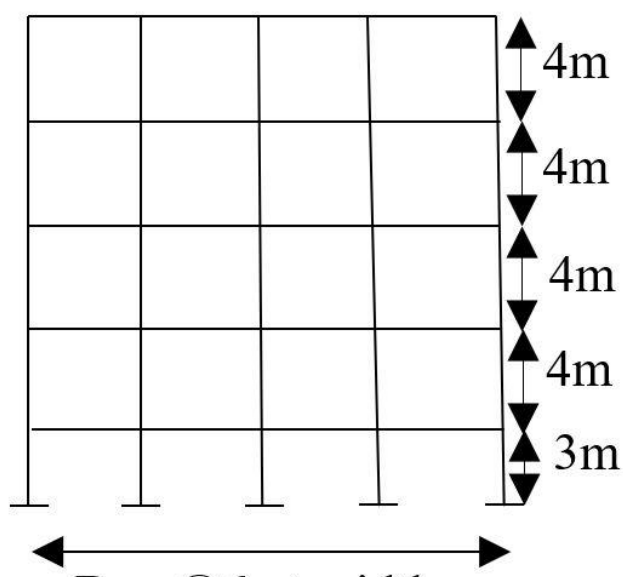

Bay@6mt width

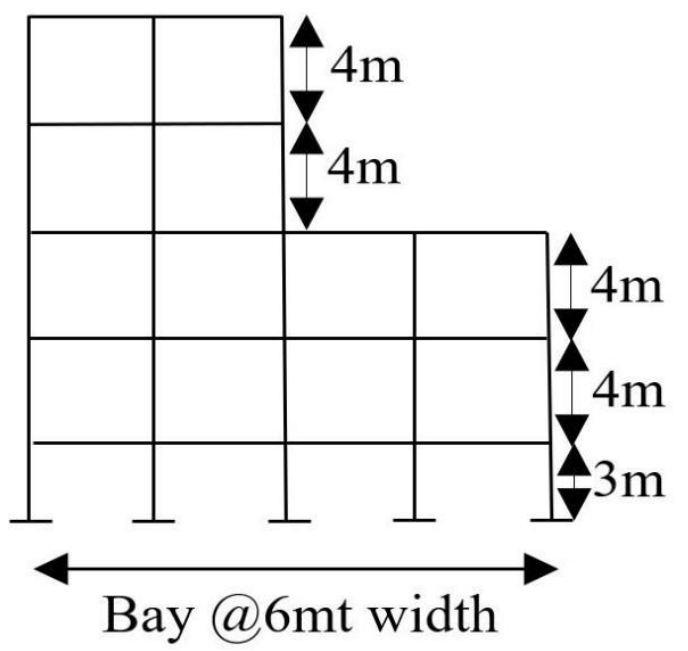


Table 1 Isolator properties for regular and irregular buildings $(\mathrm{Tb}=3 \mathrm{Ts})$

\begin{tabular}{|c|c|c|c|c|c|c|c|c|c|c|}
\hline \multirow{2}{*}{$\begin{array}{l}\text { Isolator } \\
\text { propertie } \\
\mathrm{S}\end{array}$} & \multicolumn{5}{|c|}{ Regular Building } & \multicolumn{5}{|c|}{ Irregular Building } \\
\hline & $\begin{array}{l}\text { Colum } \\
\mathrm{n} 1\end{array}$ & $\begin{array}{l}\text { Colum } \\
\text { n } 2\end{array}$ & $\begin{array}{l}\text { Colum } \\
\text { n } 3\end{array}$ & $\begin{array}{l}\text { Colum } \\
\mathrm{n} 4\end{array}$ & $\begin{array}{l}\text { Colum } \\
\text { n } 5\end{array}$ & $\begin{array}{l}\text { Colum } \\
\mathrm{n} 1\end{array}$ & $\begin{array}{l}\text { Colum } \\
\mathrm{n} 2\end{array}$ & $\begin{array}{l}\text { Colum } \\
\text { n } 3\end{array}$ & $\begin{array}{l}\text { Colum } \\
\mathrm{n} 4\end{array}$ & $\begin{array}{l}\text { Colum } \\
\text { n } 5\end{array}$ \\
\hline $\begin{array}{l}\text { Effective } \\
\text { Stiffness } \\
\left(\mathrm{K}_{\text {eff }}\right)\end{array}$ & 153.54 & $\begin{array}{l}231.55 \\
7\end{array}$ & $\begin{array}{l}230.45 \\
8\end{array}$ & $\begin{array}{l}231.55 \\
7\end{array}$ & 153.54 & 152.92 & 232.30 & 199.01 & 140.06 & 88.34 \\
\hline $\begin{array}{l}\text { Yield } \\
\text { stress } \\
(\mathrm{Q}) \\
\text { Post } \\
\text { yield } \\
\text { stiffness } \\
\text { ratio }(\alpha)\end{array}$ & 17.18 & 25.9 & 25.79 & 25.9 & 17.18 & 17.1 & 25.9 & 22.25 & 15.66 & 9.87 \\
\hline
\end{tabular}

Table 2 Peak responses of fixed-base regular building under dynamic loadings

\begin{tabular}{|c|c|c|c|c|c|}
\hline $\begin{array}{l}\text { Ground } \\
\text { Excitation }\end{array}$ & $\begin{array}{l}\text { Peak top Storey } \\
\operatorname{drift}(\mathrm{mm})\end{array}$ & $\begin{array}{l}\text { Peak top Storey } \\
\text { displacement(mm) }\end{array}$ & $\begin{array}{l}\text { Peak top Storey } \\
\text { absolute } \\
\text { acceleration }\left(\mathrm{m} / \mathrm{s}^{2}\right)\end{array}$ & $\begin{array}{l}\text { Peak } \\
\text { maximum } \\
\text { bending } \\
\text { moment } \\
(\mathrm{kNm})\end{array}$ & $\begin{array}{l}\text { Peak } \\
\text { maximum } \\
\text { base } \\
\text { shear }(\mathrm{kN})\end{array}$ \\
\hline Blast1 & 5.45 & 42.384 & 22.34 & 9955.16 & 669.085 \\
\hline Blast2 & 10.661 & 82.85 & 43.68 & 19459.96 & 1307.09 \\
\hline Blast3 & 17.701 & 137.561 & 72.52 & 32310.6 & 2171.59 \\
\hline Blast4 & 23.813 & 185.058 & 97.56 & 43466.61 & 2921.38 \\
\hline $\begin{array}{l}\text { Imperial } \\
\text { Valley }\end{array}$ & 4.782 & 50.984 & 8.05 & 8652.40 & 717.864 \\
\hline Kern & 3.029 & 30.461 & 5.43 & 5596.566 & 475.927 \\
\hline Loma & 1.862 & 19.046 & 3.46 & 3646.891 & 270.767 \\
\hline Northridge & 21.322 & 195.504 & 47.28 & 45224.96 & 3354.37 \\
\hline
\end{tabular}

Table 3 Peak responses of fixed-base irregular building under dynamic loadings

\begin{tabular}{|c|c|c|c|c|c|}
\hline $\begin{array}{l}\text { Ground } \\
\text { Excitation }\end{array}$ & $\begin{array}{l}\text { Peak top Storey } \\
\operatorname{drift}(\mathrm{mm})\end{array}$ & $\begin{array}{l}\text { Peak top Storey } \\
\text { displacement }(\mathrm{mm})\end{array}$ & $\begin{array}{l}\text { Peak top Storey } \\
\text { absolute } \\
\text { acceleration }\left(\mathrm{m} / \mathrm{s}^{2}\right)\end{array}$ & $\begin{array}{l}\text { Peak } \\
\text { maximum } \\
\text { base shear } \\
(\mathrm{kN})\end{array}$ & $\begin{array}{l}\text { Peak } \\
\text { maximum } \\
\text { bending } \\
\text { moment } \\
(\mathrm{kNm})\end{array}$ \\
\hline Blast1 & 4.678 & 36.694 & 28.87 & 646.475 & 7971.72 \\
\hline Blast2 & 9.144 & 71.72 & 56.43 & 1263.702 & $15582 . .79$ \\
\hline Blast3 & 15.182 & 119.094 & 93.70 & 2098.207 & 25873.13 \\
\hline Blast4 & 20.424 & 160.215 & 126.05 & 2822 & 34806.44 \\
\hline $\begin{array}{l}\text { Imperial } \\
\text { Valley }\end{array}$ & 4.745 & 34.048 & 10.83 & 498.429 & 5970.80 \\
\hline Kern & 3.07 & 23.007 & 6.47 & 325.786 & 3956.77 \\
\hline Loma & 3.017 & 18.886 & 6.71 & 279.447 & 3492.62 \\
\hline Northridge & 24.669 & 167.297 & 56.82 & 2645.515 & 32161.5 \\
\hline
\end{tabular}


Table 4 Performance of base-isolated regular building under dynamic loadings

$\begin{array}{llll}\text { Ground } & \mathrm{T}_{\mathrm{b}}=2 \mathrm{~T}_{\mathrm{S}} & \mathrm{T}_{\mathrm{b}}=2.5 \mathrm{~T}_{\mathrm{S}} & \mathrm{T}_{\mathrm{b}}=3 \mathrm{~T}_{\mathrm{S}} \\ \text { Excitation } & & \end{array}$

\begin{tabular}{lllllll}
\hline & $\begin{array}{l}\text { Reduced } \\
\text { maximum } \\
\text { base shear } \\
(\%)\end{array}$ & $\begin{array}{l}\text { Reduced } \\
\text { maximum } \\
\text { bending } \\
\text { moment(\%) }\end{array}$ & $\begin{array}{l}\text { Reduced } \\
\text { maximum } \\
\text { base shear } \\
(\%)\end{array}$ & $\begin{array}{l}\text { Reduced } \\
\text { maximum } \\
\text { bending } \\
\text { moment(\%) }\end{array}$ & $\begin{array}{l}\text { Reduced } \\
\text { maximum } \\
\text { base shear } \\
(\%)\end{array}$ & $\begin{array}{l}\text { Reduced } \\
\text { maximum } \\
\text { bending } \\
\text { moment(\%) }\end{array}$ \\
\hline Blast1 & 86.33 & 43.63 & 86.16 & 48.02 & 86.3 & 51.45 \\
Blast2 & 94.79 & 58.59 & 94.08 & 64.16 & 93.5 & 67.3 \\
Blast3 & 96.14 & 63.60 & 97 & 69.58 & 97.07 & 73.2 \\
Blast4 & 95.53 & 65.16 & 96.8 & 71.31 & 97.57 & 75.3 \\
Imperial & 85.58 & 56.54 & 85.78 & 60.822 & 86.34 & 57.499 \\
Valley & & & 78.14 & 35.02 & 82.47 & 45.71 \\
Kern & 77.12 & 26.42 & 79.67 & 20.69 & 84.59 & 45.72 \\
Loma & 75.03 & 24.204 & 84 & 70.13 & 88.44 & 75.8 \\
Northridge & 78.16 & 59.64 & & & & \\
\hline
\end{tabular}

Table 5 Performance of base-isolated irregular building under dynamic loadings

\begin{tabular}{|c|c|c|c|c|c|c|}
\hline Ground & $\mathrm{T}_{\mathrm{b}}=2 \mathrm{~T}_{\mathrm{S}}$ & & $\mathrm{T}_{\mathrm{b}}=2.5 \mathrm{~T}_{\mathrm{s}}$ & & $\mathrm{T}_{\mathrm{b}}=3 \mathrm{~T}_{\mathrm{s}}$ & \\
\hline & $\begin{array}{l}\text { Reduced } \\
\text { maximum } \\
\text { base shear } \\
(\%)\end{array}$ & $\begin{array}{l}\text { Reduced } \\
\text { maximum } \\
\text { bending moment } \\
(\%)\end{array}$ & $\begin{array}{l}\text { Reduced } \\
\text { maximum } \\
\text { base shear (\%) }\end{array}$ & $\begin{array}{l}\text { Reduced } \\
\text { maximum } \\
\text { bending } \\
\text { moment (\%) }\end{array}$ & $\begin{array}{l}\text { Reduced } \\
\text { maximum } \\
\text { base shear } \\
(\%)\end{array}$ & $\begin{array}{l}\text { Reduced } \\
\text { maximum } \\
\text { bending } \\
\text { moment (\%) }\end{array}$ \\
\hline Blast1 & 87.05 & 43.50 & 88.68 & 47.83 & 87.07 & 51.43 \\
\hline Blast2 & 95.17 & 58.78 & 94.41 & 63.71 & 93.89 & 67.26 \\
\hline Blast3 & 96.38 & 63.13 & 97.19 & 69.37 & 97.28 & 73.08 \\
\hline Blast4 & 95.75 & 64.85 & 97.04 & 70.90 & 97.71 & 75.06 \\
\hline $\begin{array}{l}\text { Imperial } \\
\text { Valley }\end{array}$ & 75.85 & 37.61 & 76.26 & 43.66 & 77.18 & 38.74 \\
\hline Kern & 66.5 & 20.03 & 75.90 & 34.75 & 74.22 & 46.61 \\
\hline Loma & 70.63 & 21.2 & 67.93 & 21.85 & 81.60 & 20.26 \\
\hline Northridge & 72.63 & 48.86 & 79.966 & 61.98 & 85.52 & 69.23 \\
\hline
\end{tabular}

Table 6 Percentage of energy dissipated by the passive system installed in regular buildings

\begin{tabular}{lllllllll}
\hline Passive System & Blast 1 & Blast 2 & Blast 3 & $\begin{array}{l}\text { Blast } \\
4\end{array}$ & $\begin{array}{l}\text { Imperial } \\
\text { Valley }\end{array}$ & Loma & Kern & Northridge \\
\hline LRB $\left(\mathrm{T}_{\mathrm{b}}=2 \mathrm{~T}_{\mathrm{s}}\right)$ & 69.83 & 72.88 & 66.04 & 63.98 & 49.88 & 57.14 & 28.07 & 52.48 \\
$\mathrm{LRB}\left(\mathrm{T}_{\mathrm{b}}=2.5 \mathrm{~T}_{\mathrm{s}}\right)$ & 65.86 & 73.44 & 70.45 & 65.85 & 49.65 & 43.41 & 17.07 & 59.12 \\
$\mathrm{LRB}\left(\mathrm{T}_{\mathrm{b}}=3 \mathrm{~T}_{\mathrm{s}}\right)$ & 60.46 & 72.99 & 71.81 & 67.80 & 47.47 & 23.23 & 30.34 & 60.46 \\
\hline
\end{tabular}


Table 7 Percentage of energy dissipated by the passive system installed in irregular buildings

\begin{tabular}{lcccccccc}
\hline Passive System & Blast 1 & Blast 2 & Blast 3 & $\begin{array}{l}\text { Blast } \\
4\end{array}$ & $\begin{array}{l}\text { Imperial } \\
\text { Valley }\end{array}$ & Loma & Kern & Northridge \\
\hline $\mathrm{LRB}\left(\mathrm{T}_{\mathrm{b}}=2 \mathrm{~T}_{\mathrm{s}}\right)$ & 70.14 & 72.87 & 65.95 & 64.08 & 50.38 & 58.08 & 29.06 & 52.33 \\
$\mathrm{LRB}\left(\mathrm{T}_{\mathrm{b}}=2.5 \mathrm{~T}_{\mathrm{s}}\right)$ & 65.84 & 73.49 & 69.67 & 64.87 & 49.88 & 43.27 & 17.29 & 57.01 \\
$\mathrm{LRB}\left(\mathrm{T}_{\mathrm{b}}=3 \mathrm{~T}_{\mathrm{s}}\right)$ & 60.93 & 73.10 & 71.79 & 67.71 & 47.82 & 24.11 & 30.82 & 60.40 \\
\hline
\end{tabular}

Structural responses for base isolated structures such as decrease in percentage of storey drifts, decrease in top storey displacements and accelerations as per loads for different time devices are compared and are plotted for both regular and irregular structures in figures 1, 2 and 3 as shown below. It is observed that the efficiency of storey drift isolators is between $30 \%$ to $90 \%$ for regular frames and, as for irregular frames, the isolators considered have shown greater efficiency as storey drift reductions have increased to and above $90 \%$. Reductions in top-storey displacements and accelerations for various isolators are also between 70 percent and 90 percent as seen for both regular and irregular structure. This study also includes the comparison of force displacement for different isolators; with the less shear force resulting in maximum energy dissipation can be observed for both regular and irregular buildings in case of blast loading as shown in figures 4 and 5 below. The study also includes the observation of the amount of hysteretic energy dissipated by various isolators used in figures 6 and 7 for both structures. The isolator with $\mathrm{Tb}=3 \mathrm{Ts}$ is proved to be more effective for both normal and irregular sets, as observed from results obtained.

The hysteretic energy is evaluated using the concept of energy-conversion equation proposed by Uang and Bertero [16] and given by Equation 1, where Ei is the absolute input energy, EK is the absolute kinetic energy; it is the elastic energy of recoverable strain; the non-negative damping energy is expressed by $\mathrm{E}$.

$$
\begin{gathered}
E_{i}=E_{K}+E_{s}+E_{\xi}+E_{h} \\
E h=\int_{0}^{t} F b x d t-\frac{(F b) 2}{2 k b} \\
E d=\frac{100 E h}{E i}
\end{gathered}
$$

The irrecoverable hysteretic energy (Eh) is measured using an Eq. 3 where $\mathrm{Fb}$ is the restore

force produced in the isolating device and $\mathrm{kb}$ is the rigidity of the isolating device. Equation 4 also gets the percent dissipated energy $(\mathrm{Ed})$ by the vibration management technique. It is also found that in the case of seismic excitations an increase in the isolation time reduces the dissipated energy along with the input energy.

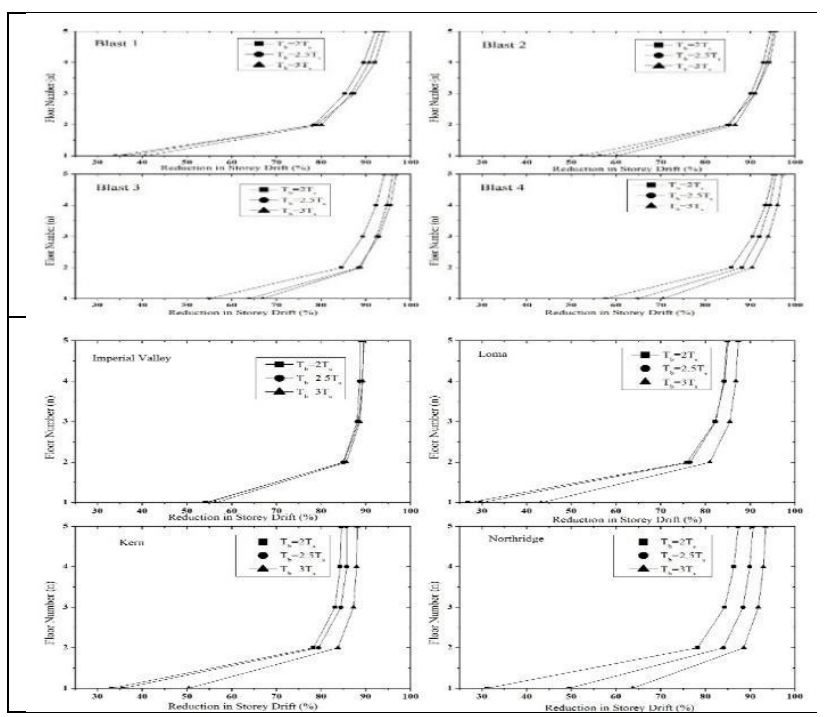

Fig 1 Reduction in Storey Drift (\%) in base-isolated regular building under dynamic excitations.

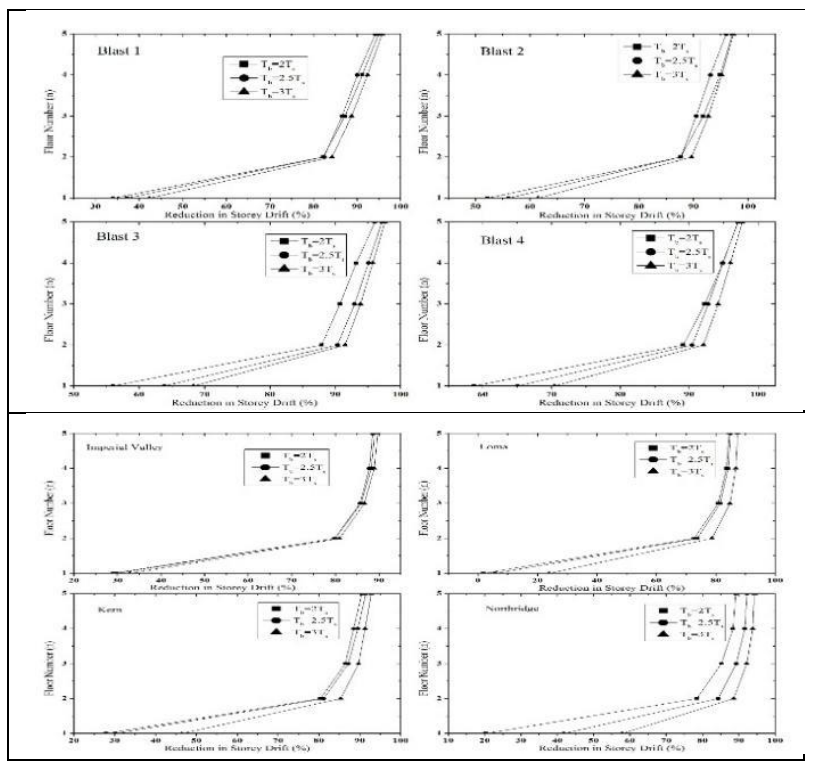

Fig.2 Reduction in storey Drift (\%) in base-isolated irregular building under dynamic excitations.

\begin{tabular}{|l|l|}
\hline $\begin{array}{l}\text { Regular Base- } \\
\text { Isolated Building }\end{array}$ & $\begin{array}{l}\text { Irregular Base- } \\
\text { Isolated Building }\end{array}$ \\
\hline
\end{tabular}




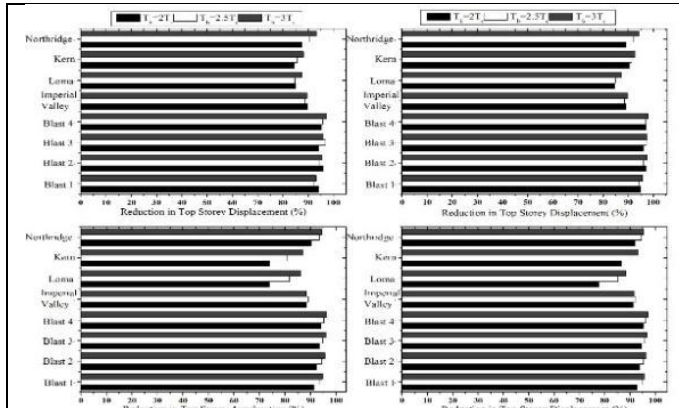

Fig 3 Performance of base-isolated buildings under dynamic excitation.

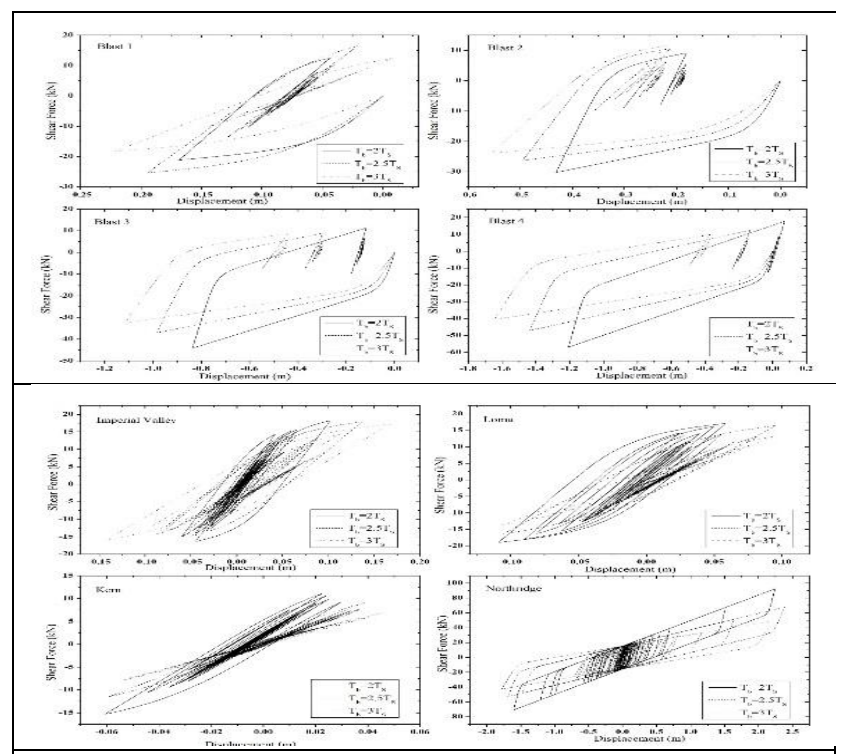

Fig 4 Force displacement behaviour of lead/rubber isolators under selected ground excitations (regular building).

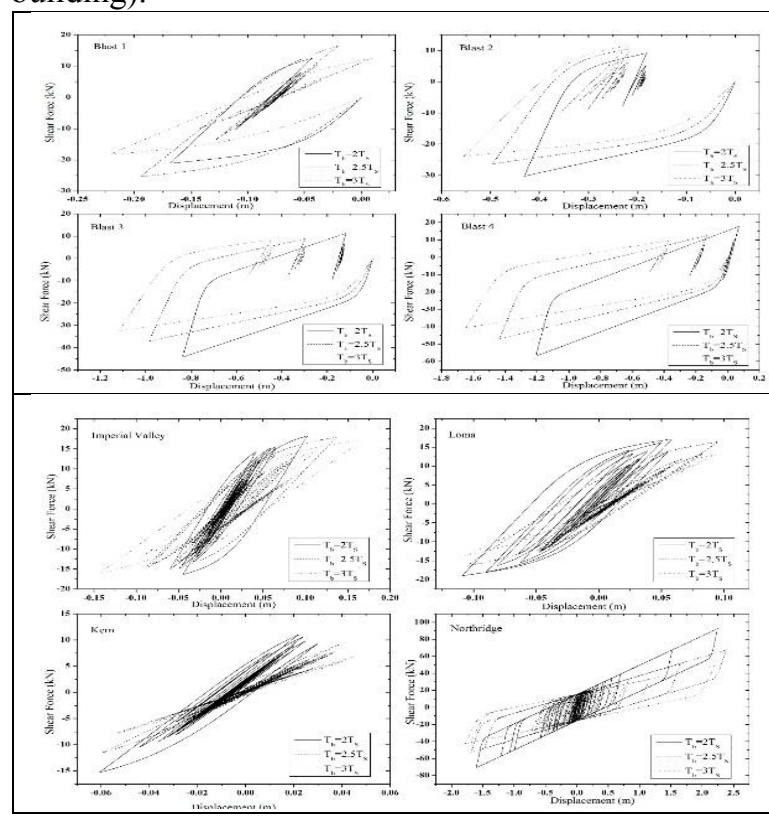

Fig 5 Force displacement behaviour of lead/rubber is lators hiffressangedtedahtatersd the performance of passive excitations (regular building).

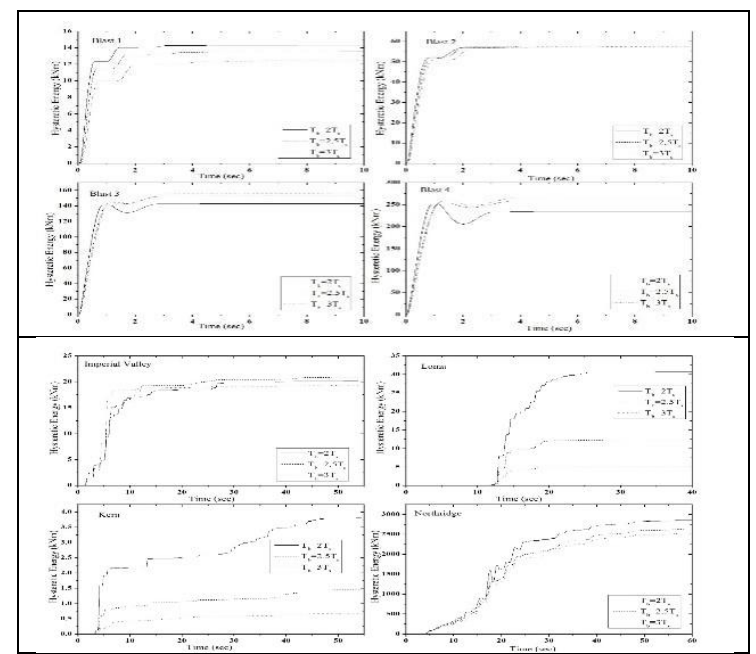

Fig 6 Energy dissipated by base isolation system in mitigating structural responses under selected excitations (regular building).

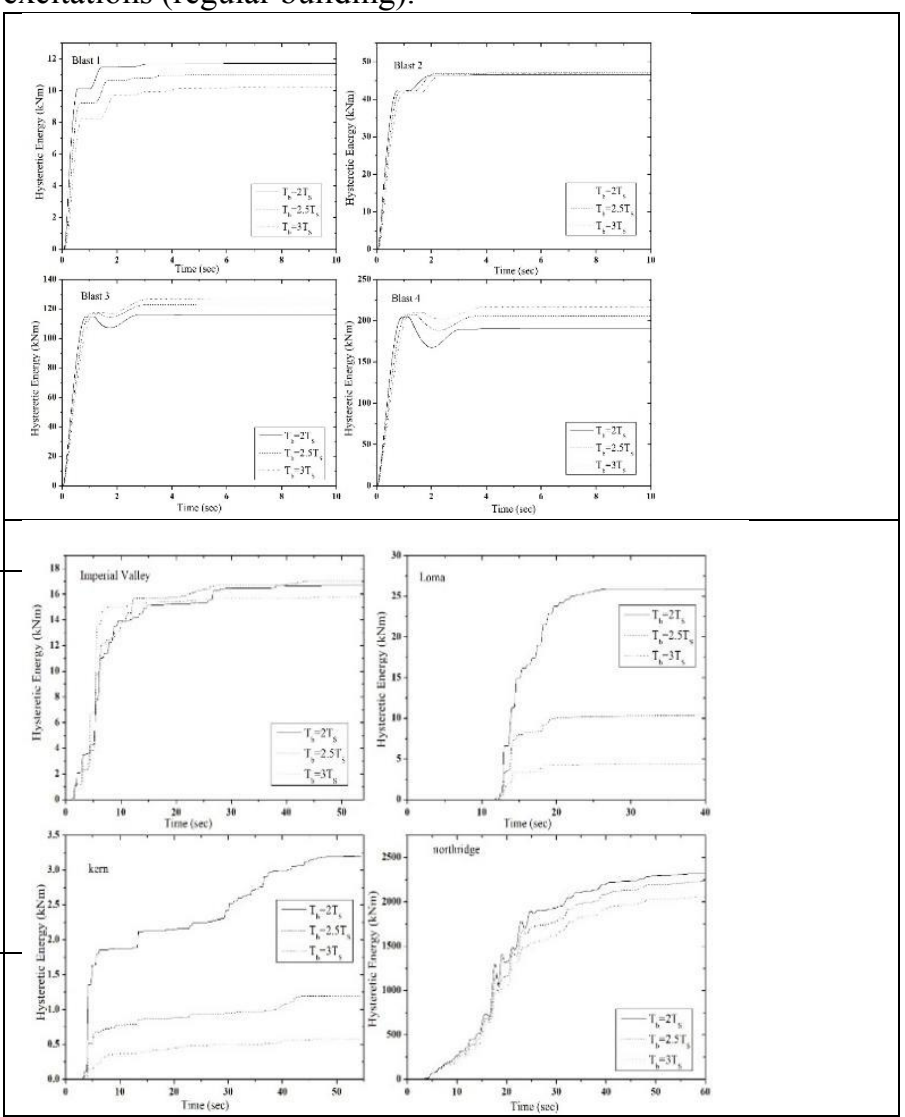

Fig 7 Energy dissipated by base isolation system in mitigating structural responses under selected excitations (regular building)

\section{Conclusion}

control techniques, i.e., base insulation system (e.g., LRB) and viscous fluid damper (FVD's). RC frames of $\mathrm{G}+4$ are considered and subject to dynamic loadings with regular and irregular conditions. As 
ground accelerations and seismic loading used are collected from the database, blast loading on frame is considered to be exponential decaying function. Isolator is planned as per isolation period i.e. $\mathrm{Tb}=$ $2 \mathrm{Ts}, \mathrm{Tb}=2.5 \mathrm{Ts}$, and $\mathrm{Tb}=3 \mathrm{Ts}$ where $\mathrm{Tb}$ is the isolation duration and Ts is the structural duration for improving its performance and the results obtained are compared to frames fitted with a damper and the following conclusions are obtained.

\section{References}

1. Draganic $\mathrm{H}$ and Vladimir S, "Blast Loading on Structures," 2012, pp.643-652.

2. Ngo T, Mendis P, Gupta A and Ramsay (2007). "Blast loading and blast effects on structures".

3. Omprakash Reddy N, Manchalwar A, "Performance of Moment Resisting RC Building Equipped With X-Plate Damper under Seismic and Blast Loading," International Journal of Innovative Technology and Exploring Engineering (IJITEE), December 2019.

4. Ranjan K, Deepankar C, and Bhargava K, "Determination of Blast Induced ground vibrations for rocks using mechanical and geological properties," Journal of Rock Mechanics and Geotechnical Engineering, 2016, pp. 341-349.

5. Kangda $Z$ and Bakre SV, "Performance of Moment Resisting Steel Frame Building Under Seismic and Blast-Induced Vibration," Journal of Vibration Engineering

6. Tummala Suresh Kumar, Kosaraju Satyanarayana, Materials Today: Proceeding, 26 (2), 3228-3233, (2020).

7. Dong B, Richard S and James MR 2016 "Seismic Response and Performance of a Steel MRF Building with Nonlinear Viscous Dampers under DBE and MCE", ASCE journal.

8. Kangda $Z$ and Bakre SV, "The Effect of LRB Parameters on Structural Responses for Blast and Seismic Loads," Arabian Journal for Science and Engineering, $25^{\text {th }}$ July 2017.
LRB isolators used for various periods of isolation have been shown to be efficient in dissipating the structural responses and it is found that isolators are more efficient for irregular frame than normal frame. Isolator with $\mathrm{Tb}=3 \mathrm{Ts}$ isolation time has maximum percentage in structural response reduction.

9. Kangda $Z$ and Bakre SV, "Positive-Phase Blast Effects on Base-Isolated Structures," Arabian Journal for Science and Engineering, $11^{\text {th }}$ Dec 2018.

10. Manchalwar A and Bakre SV, "Seismic response control of building with optimal location of metallic dampers," The Institution of Engineers, Structures and Buildings, Oct. 2018.

11. Manchalwar A and Bakre SV, "Performance of RC Structures Equipped with Steel and Aluminium X-Plate Dampers," vol.97, Dec. 2016, pp.415-425.

12. Manchalwar A and Bakre SV, "Optimization of Metallic Damper Location for Seismic Response Control," Journal of Vibration Engineering and Technologies, 2019, pp.261275.

13. Manchalwar A and Bakre SV, "Seismic performance of structure with isolated foundation using u-shape steel damper as an isolator," Journal of Soil mechanics and Foundation Engineering, 2020.

14. Manchalwar A and Bakre SV, "Vibration control of structure by top base isolated storey as tuned damper," Journal of Dynamics and Control, $20^{\text {th }}$ February 2020.

15. Mondal A, Ghosh S, Reddy GR, "Performance-based evaluation of response reduction factor for ductile RC frames," Journal of Engineering Structures, 2013.

16. Uang CM, Bertero VV (1990) Evaluation of seismic energy in structures. Earthquake Eng Struct Dyn 19(1):77-90. 